\title{
RELIABLE EVIDENCE OF INVOLVEMENT OF THE KININ SYSTEM IN MOUSE MALARIA
}

\author{
Hiroshi OHTOMO* and Makolo KATORL** \\ Department of Medical Zoology, Faculty of Medicine* and Depariment of \\ Pharmacology, Institute for Cardiovascular Diseases $* *$, Tokyo \\ Medical and Dontal University, Bunkyo-ku, Tokyo, Japan \\ Received for publication December 16, 1971
}

The pharmacology of bradykinin has enticed investigators to prove the involvement of the kinin system in various pathological states, including protozoan diseases.

In Plasmodium knowlesi malaria of rhesus monkeys, the significance of the kinin system was reported by British investigators, who showed that plasmat kininogen of the infected primates was almost depleted near death, in spite of tailure of the detection of free kinin in the plasma $(1,2)$. In addition, the increase of katlikrein contents and kininase activity in plasma were also reported in the infected monkeys $(2,3)$.

On the other hand, Urbanitz, et al. claimed that the reduced concentration of plasma kininogen did not mean directly the involvement of the kinin system in various types of shock, because the reduction of plasma kininogen levels was simultaneously accompanied with the reduction of plasma protein concentration in shocks $(4,5)$.

As it is known that plasma protein concentration decreases gradually with the increased degree of parasitaemia in the monkey malaria (6), the apparent reduction of plasma kininogen in the infection mentioned above may be one of the features of the general prostration without true consumption of kininogen and release of kinin. Therefore, the reduction of kininogen in malaria must be re-examined in these respects.

The present paper reports, in the severe cases of mice infected with Plasmodium berghei (NK 65), the success of the detection of free kinin in venous blood and the real consumption of plasma kininogen. The latter finding was supported by the reduction of the concentration expressed in $/ \mathrm{gg} / \mathrm{mg}$ protein or globulin. Its pathophysiological significance is also discussed.

\section{MATERIALS AND METHODS}

\section{Infections}

Plasmodium berghei (NK 65) was used for the infection of malaria to mice. The strain, isolated by Yoeli (7), was kindly supplied in September 1969 by Department of Bacterial Infection, The Institute of Medical Science, University of Tokyo. The maintenance for experiments was done by i.p. inoculation of mice usually every live days. For the

** Present address: Department of Pharmacology, Kitasato University School of Medicine, Asamizodai, Sagamihara, Kanagawa-ken, Japan. 
infection experiments, healthy female mice of dd-strain, weighing 19-21 g, were inoculated i.p. with $0.1-0.2 \mathrm{ml}$ of infected mouse blood, diluted with saline, which contained approx. $10^{7}$ of parasitized red cells. Infected mice were housed at approx. $25^{\circ} \mathrm{C}$. As the infection was fatal on around day 7 of inoculation, blood samples were collected from mice on the day 7 . Day 1 equals $24 \mathrm{hr}$ after inoculation. Non-infected control mice were fed parallelly in the same condition and used for experiments on the same day as the infected mice.

\section{Parasite counts}

This was done on the blood thin films obtained from the collected blood of the infected animals. The degree of parasitaemia is expressed in percentage of the infected erythrocytes to thousand non-parasitized red cells.

\section{Blood collection}

Infected and non-infected mice were anesthetized with pentobarbital sodium (50 $\mathrm{mg} / \mathrm{kg}$ i.p.). In the initial few experiments, blood samples were collected by cardiac puncture using a disposable needle and a plastic syringe. Because of haemolysis, however, in most other cases this procedure was replaced by collection from the carotid artery throughathin cannula (PE-10). Blood was drawn slowly and carefully, by a plastic syringe moistened with heparin $(250 \mathrm{u} / \mathrm{ml})$. Haemolysis was avoided carefully and haemolyzed plasma was discarded. $0.8-1.2 \mathrm{ml}$ of the blood was obtained from the carotid artery using this procedure. The blood placed in small plastic tubes was entrifuged at $0 \mathrm{C}$ for $30 \mathrm{~min}$ at $4000 \mathrm{G}$. The plasma oblained was used for the determination of kininogen, protein, electrophoresis and kininase activity. Haematocrit values were determined with $0.05 \mathrm{ml}$ of blood by Kokusan microhaematocrit centrifuge. Contacts with glass as well as negative surfaces were carefully avoided.

\section{Bioassay of kinin}

The isolated rat uterus preparation was used for determination of frec kinin, kininogen and kininase activity. Virgin rats weighing $120-200 \mathrm{~g}$ were injected i.p. and s.c. with $7.5 \mathrm{mg}$ of hexestrol (Hexron, Teikoku Zöki) 12-24 hr before assay. One horn of the separated uterus was suspended at $28 \mathrm{C}$ in $5 \mathrm{ml}$ organ bath filled by acrated Munsick solution in the presence of $10^{-7} \mathrm{~g} / \mathrm{ml}$ of 2-bromolysergic acid diethylamide (BOL, Sandoz). The contractions of the ulerus were recorded using a frontal writing lever. Synthetic bradykinin (Peptide Centre, Institute for Protein Rescarch, Osaka University, Osaka) was used as a standard. The contact time for each sample was $90 \mathrm{sec}$, and the interval between tests was 4 to $5 \mathrm{~min}$. Munsick solution contained $\mathrm{NaCl} 114.0 \mathrm{mM}, \mathrm{KCl} 6.2 \mathrm{mM}, \mathrm{CaCl}_{2}$ $0.5 \mathrm{mM}, \mathrm{NaH}_{3} \mathrm{PO}_{+} 1.0 \mathrm{mM}, \mathrm{NaHCO}_{3} 30.0 \mathrm{mM}$, glucose $0.5 \mathrm{~g}$ in distilied water 1.01 (8).

\section{Extraction of rinin}

Blood was collected from the jugular vein of infected and non-infected mice in the same way as the method used for blood collection from the carotid artery. A half $\mathrm{ml}$ of blood was almost the total amount which could be collected from jugular vein of mice using this method. The volume of the venous blood was ejected into $15 \mathrm{ml}$ of chilled $80 \%(\mathrm{v} / \mathrm{v})$ ethanol in polyethylene tube and kinin was extracted according to the method reported by 
Brocklehurst and Zeitlin (9). The dried residues were stored at $20 \mathrm{C}$ and dissolved in $0.5 \mathrm{ml}$ of warm Munsick solution immediately before assay. Because of the small amount of venous blood (about $0.5 \mathrm{ml}$ ), the sensitivity of the rat uterus was increased by reducing the load on the uterus, so that $0.1 \mathrm{ng} / \mathrm{ml}$ of hradykinin in the organ bath contracted the uterus by $1-30 \mathrm{~mm}$ on the record.

The four recovery experiments were made with 1 , g of baldykinin, added $1080 \%$ ethanol at the same time as addition of blood from control mice. The values obtained were $57.0,52.0,50.0$ and $56.0 \%$. The values of recovery for four other experiments with human blood samples were $69.3,78.4,64.6$ and $70.7 \%$, (mean $70.8^{\circ}$ ).

\section{Total kininogen}

The determination of plasma kininggen was done according to the method reported by Diniz and Carvalho (10). Acidified, denatured plasmat of mice were incubated for 30) min with trypsin (Nutritional Biochemical Corporation, U.S.A.) and released bratykinin was extracted with alcohol. The dried residues were stored at 200 : until use. Kinin in $0.05 \mathrm{ml}$ of sample dissolved in $4 \mathrm{ml}$ of Munsick solution was assiyed on the rat uterus. Recently, it was reported that the method also produced potentiator(s) of bradykinin (11, 12). Although this was confirmed in our laboratory (to be published), kininogen determination in these experiments was performed by the original melhod will the following special attentions: The volume of Munsick solution requried to dissolve dried residues and samples to be put into the organ bath was restricted $104 \mathrm{ml}$ and $0.05 \mathrm{ml}$ respectively.

Plasma rininase activity

Synthetic bradykinin $(1$, ag) was incubated with $0.05 \mathrm{ml}$ of plasnla from normal and infected mice at $37 \mathrm{C}$ in the presence of soy bean trypsin inhibitor $(0.2 \mathrm{mg}$ ) (Calbiochem, L.S.A). The tinal volume of the incubation mixture was adjusted to $2 \mathrm{ml}$ with $0.1 \mathrm{M}$ phosphate buffer (pH 7.4). $0.05 \mathrm{ml}$ of the incubation mixture was removed and assayed on the rat uterus at 5 min intervals for residual kinin activity. Kininase activity was expressed in terms of the half-life of bradykinin.

Plasma protcin deformination

The method reported by Lowry et al. (13) was used in most experiments, but, at the beginning of the experiment, the determination was done by relactometer. As protein values determined by both methods were not significantly different within the values in the experiments, all values were incorporated into the figures.

AG ratio of plasma protein by chectrophoresis

To obtain albumin-globulin ratio with the limited volume of the mouse plasma, elestrophoresis on cellulose acetate membrane (Sartorius Membrantilter GmbH, Germany) was used. Four al of plasma was used for fractionation. Both albumin and globulin fractions were stained and extracted with $3.5 \mathrm{ml}$ of $0.01 \mathrm{~N} \mathrm{NaOH}$. The colour in $\mathrm{NaOH}$ solution was read at $510 \mathrm{~m} /$ by spectrophotometcr. Unstained part of the membrane was used for a blank. $A / G$ ratio was calculated from extinctions of both albumin and globulin. The plasma concentrations of both fractions were calculated from the total protein concentration. 
Measurement of blood pressure of mice

Infected and non-infected control mice were anesthetized with pentobarbital sodium (50 $\mathrm{mg} / \mathrm{kg}$ i.p.). Systemic arterial pressure was measured by high pressure transducer (Nihon Kohden, MPU-0.5) connected to the thin cannula (PE-10) inserted to the carotid artery of the mice. Respiratory movements of the thorax were traced by straingage transducer (Nihon Kohden, SB-1T) and both were recorded on an ink-writing oscillograph.

In relation to the blood pressure experiment, bradykinin potentiator $\mathrm{C}$ was used for proof of the circulating kinin. The peptide is one of five bradykinin potentiators isolated from the venom of a snake (Agkistrodon halys blomhoffii) and was kindly supplied by Dr. H. Kato and Prof. T. Suzuki, Institute for Protein Research, Osaka University.

\section{RLSULTS}

\section{Infection}

Mice infected with Plasmoditm berghei (NK 65) showed no appreciable pathological phenomena until day 3 of infection. Around day 5 after infection, pathological features became evident gradually: Body weight stopped increasing or rather it decreased, and the mice showed dullness in action, piloelection, decreased food intake, closed eyelids, pale and cold skin, particulary in tail and ears, and anemia. General prostration was evident even macroscopically. Some mice died from around day 6 of infection.

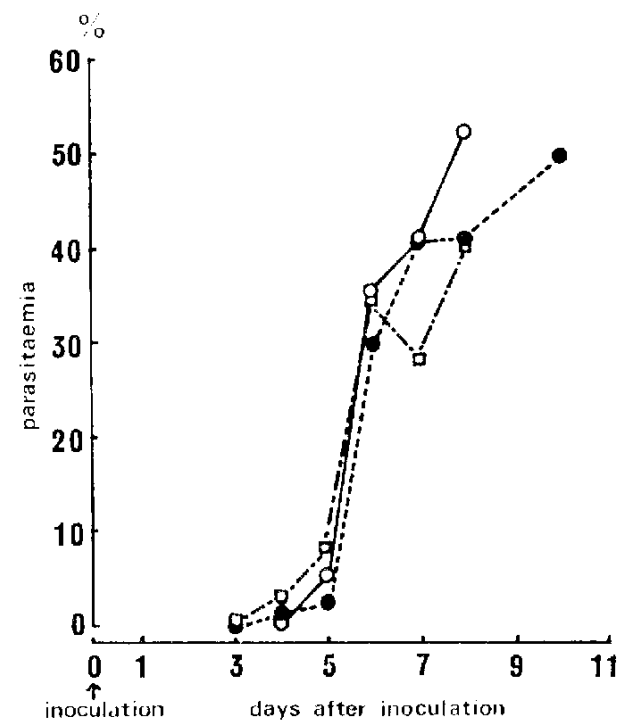

FIG. 1. Increase in the degree of parasitaemia of three mice in the time course after inoculation.

Three mice were inoculated i.p. with approx, $10^{7}$ parasitized red cells. Ordinate, the degrees of parasitaenia $(\%)$; abscissa, days after inoculation.

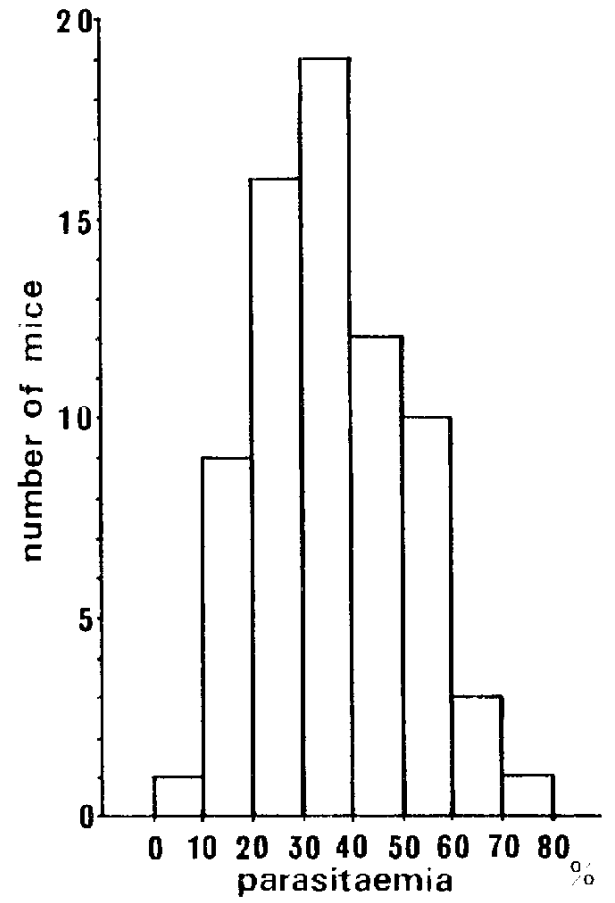

FIG. 2. Distribution of parasitaemia in seventy-one inice on day 7 of infection.

Ordinate, number of mice; abscissa, the degrees of parasitaemia $(\%)$. 
Fig. 1 depicts the results from pilot study, with three mice in which the degrees of parasitaemia were followed after inoculation. The parasite count for the pilot study was made with 200 red cells on the film of blood taken by pricking tail. Parasitaemia did not increase before day 3 of infection, whereas it increased suddenly between day 5 and 6 , and further from day 7 onwards. The parasitaemia of 71 infected mice on day 7 was $30-40 \%$ at the peak and was distributed evenly to both sides from 4 to $72 \%$ as shown in Fig. 2 . In the following experiments, results were grouped tentatively into two, so that mice with parasitaemia of less than $30 \%$ were grouped as the mild cases, whereas 1hose with more

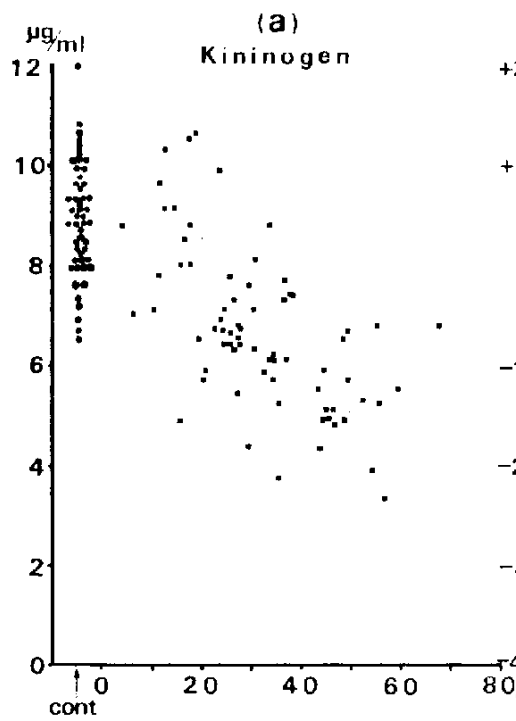

(C)

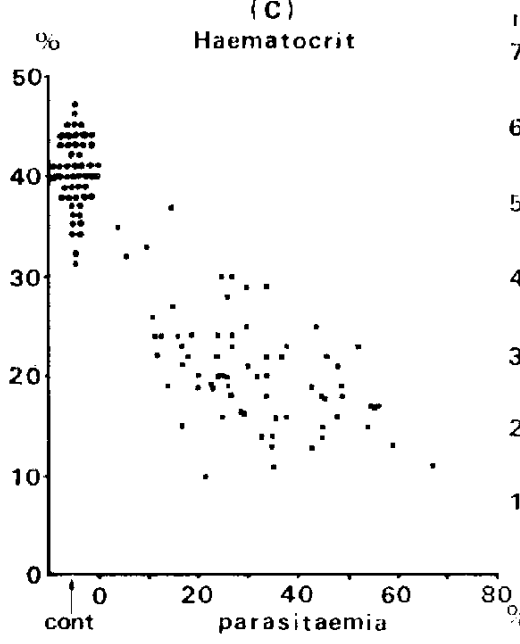

(b)

Body weight

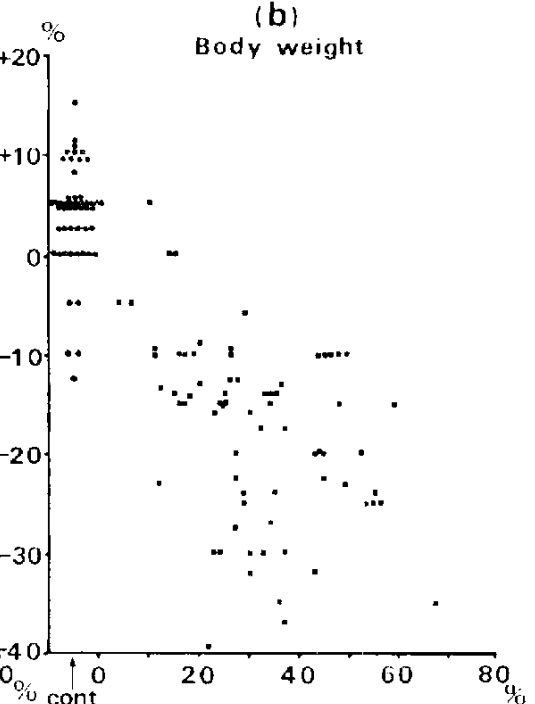

(d)

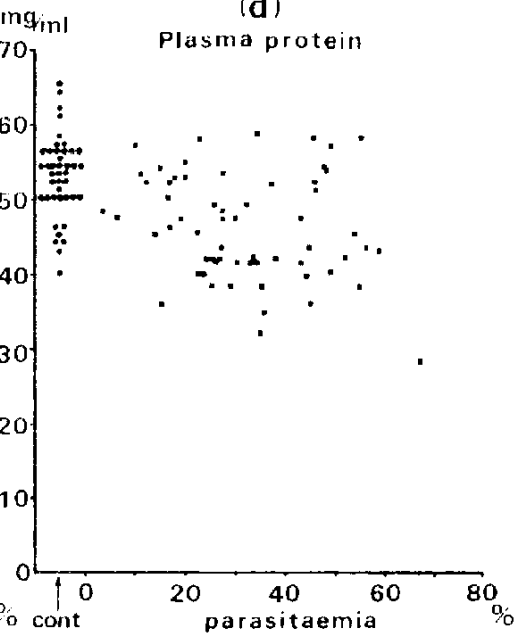

FIG. 3. Relationship of kininogen, body weight, haenatocrit and total plasma protein to parasitaemia in the infected and the non-infiected, control

mice.

a) kininogen $(\mu \mathrm{g} / \mathrm{ml})$; b) body weight $(\%)$; C) haematocrit $(\%)$; d) plasma protein $(\mathrm{mg} / \mathrm{ml})$. Abscissa, the degrees of parasitaemia $(\%)$; Cont, control mice. 
than $30 \%$ the severe cases.

\section{Total kininogen}

Fig. 3 (a) shows the total plasma kininogen contents per ml plasma of infected and non-infected control mice, plotted against the parasitaemia of each mouse. The total kininogen contents of 71 infected mice decreased with the increased degree of parasitaemia. The kininogen in the severer cases was obviously lower, compared with those of 51 noninfected mice. However, the decreased concentration of the kininogen of the infected mice may not always mean the consumption of the kininogen, because platsma protein as well as body weight and haematocrit of the infected mice decreased with the increased degree of

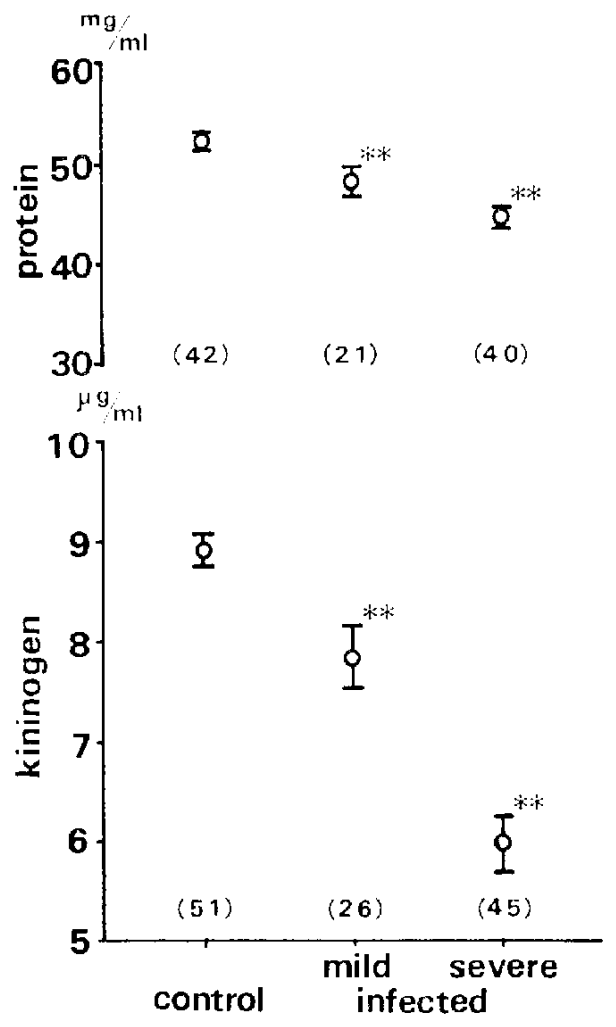

Fig. 4. Changes of total plasma protein and kininogen in the control mice and in the mild and the severe cases of the infected mice.

Mice with parasitaenia below $30 \%$ were grouped as mild cases, whereas those with above $30 \%$ as severe cases. The kininogen concentrations per $\mathrm{ml}$ plasma (f!g/ml) were significantly lower in the infected mice than in the control, as were the total plasma protein concentrations (mg $\mathrm{ml}$ ) in the infected mice. The numbers of mice used are shown in parenthesis. Mean standard error. : ${ }^{*} \mathrm{p}<0.01$.

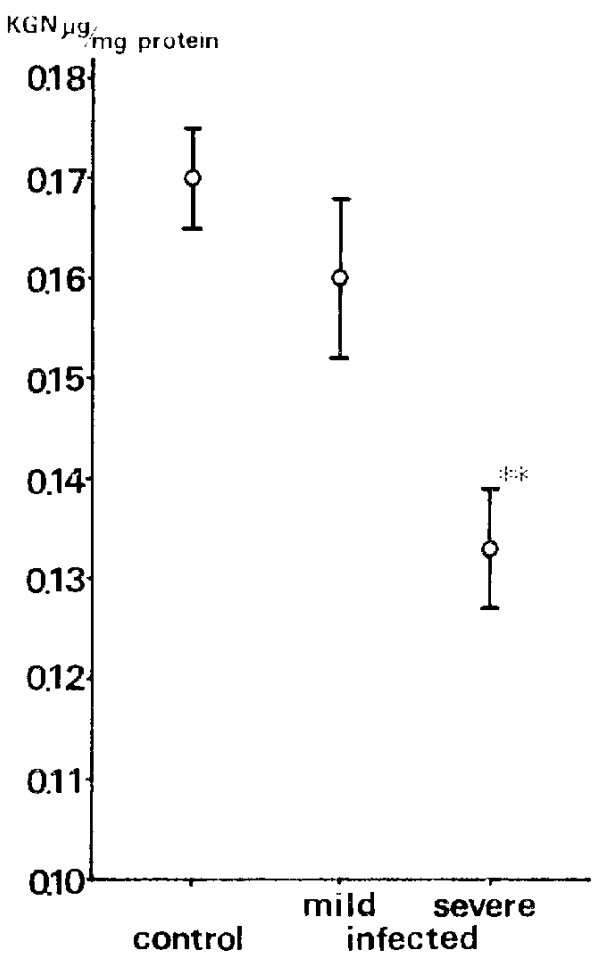

FIG. 5. Kininogen contents expressed as per my protein in the control and the infected mice.

The kininogen content was lower only in the severe cases $\left({ }^{*} p<0.01\right)$ than in the control group. The numbers of nice used were $42,21,40$ for the control, mild and severe cases respectively. KGN, kininogen. Mean $\perp$ standard error. 
parasitacmia as shown in Fig. 3 (b)(c)(d). In fact, although mean $3.8 \%$ increase of body weight was shown in all the control mice for 7 days, the infected animals showed a marked decrease in body weight, according to the severity of the disease. Haematocrit was also reduced in the infected group. Plasma protein concentration decreased with the increased parasitaemia as well, although the slope was not so steep. The relationship between the total plasma kininogen and the plasma protein is illustrated in Fig. 4. The kininogen contents of the non-infected, control mice were compared with two groups of the infected mice; the mild cases (less than $30 \%$ in parasitamia) and the severe cases (more than $30 \%$ ). The total kininogen of the severe cases (mean $\perp$ S.E., $6.00 . \perp 0.27 \mu \mathrm{g} / \mathrm{ml}$ with 45 mice) wals significantly lower $(\mathrm{p}<0.01)$ than that of the control, non-infected mice $(8.92=0.16 \mathrm{rg} / \mathrm{ml}$ with 51 mice). The difference between the mild cases $(7.86 \div 0.31 \mu \mathrm{g} / \mathrm{ml}$ with 26 mice) and the control mice was also significant $(\mathrm{p}<0.01)$. Plasma protein concentrations in the control, mild and severe groups were $52.5 \pm 0.9,48.2=1.4$ and $44.7 \pm 1.2 \mathrm{mg} / \mathrm{ml}$ of plasma respectively (mean \pm S.E.) and the latter two were significantly lower than the former (p< 0.01$)$. From these results, the possibility cannot be denied that the reduction of the total plasma kininogen was only a part of the reduced concentration of the plasma protein, without any release of kinin. If so, the kininogen concentration per mg protein of each animal must be non-significant among three groups. Resulis are illustrated in Fig. 5. The value of the severe group $(0.133 \mid 0.006 / \mathrm{gg} / \mathrm{mg})$ was definitely lower $(\mathrm{p}<0.01)$ than that of the control $(0.169 \cdot 0.004 / \mathrm{g} / \mathrm{mg})$ and the mild group $(0.159 \mid 0.007 / \mathrm{kg} / \mathrm{mg} ; \mathrm{p}<0.01)$, but there was no significant difference between the mild group and the control group ( $p_{-}$$0.2)$. Therefore it must be concluded that the true consumption of kininogen oceurred in the severe group, whereas plasma kininogen wats not consumed in the mild group, even if the kininogen per ml plasma was redued significantly.

Considering the general prostration of the infected mice, the reduced concentration of protein in plasma may be due to the decreased amount of albumin and not to that of globulin in which plasma kininogen is present. Albumin-globulin ratios obtained are shown in Table 1. Although the significant reduction was observed in the severe group $(p<0.01)$, A/G ratio of the mild group was not significantly different from that of the control group. The concentrations of albumin and globulin in three groups, calculated from the total protein concentration, are illustrated in 1 ig. 6 .

Changes of the protein concentration were very similar to those in Fig. 4, except the

'TAuf. 1. Albumin-globulin ratios of plasma protein in the control and the infected mice.

\begin{tabular}{|c|c|c|c|}
\hline & \multirow{2}{*}{ Control } & \multicolumn{2}{|c|}{ Infected } \\
\hline & & Mild & Severe \\
\hline Parasitaemia & & below $30 \%$ & above $30 \%$ \\
\hline No. of animals & 18 & 10 & 15 \\
\hline $\mathrm{A} / \mathrm{G}$ ratio & $1.40: 0.02$ & $1.33: 0.06$ & $0.95 \div 0.14^{* * *}$ \\
\hline
\end{tabular}

Mean $\because$ standard crror

** significantly lower than other two $(\mathrm{p}, 0.01)$ 
slightly higher value of the severe group $(48.4 \pm 1.2 \mathrm{mg} / \mathrm{ml})$ in this series than that in Fig. 4 $(44.7-1.2 \mathrm{mg} / \mathrm{ml})$. Albumin concentrations, as can be supposed, gradually lowered, in a reflection of the increased degrees of parasitaemia, and the mean values + S.E. obtained for the control, mild and severe groups were $32.3 \pm 0.8,27.9+1.4$ and $23.4+0.7 \mathrm{mg} / \mathrm{ml}$ respectively. This means that most of the total protein reduction during the process of the infection can be explained by the albumin reduction. On the contrary. the pattern of globulin concentration was somewhat different and interesting: Namely, that below 30\% of parasitamia $(21.0+0.8 \mathrm{mg} / \mathrm{ml})$ decreased significantly $(\mathrm{p}<0.05)$ from that of control (23.1 $0.4 \mathrm{mg} / \mathrm{ml}$ ), but the glotulin concentration increased again in the parasitaemia above $30^{\circ} .(25.0+0.8 \mathrm{mgrm} ; \mathrm{p}, 0.05)$ and the value exceeded significantly that of the control group. The increased value of globulin in the severe group may explain partly the higher value of the total protein (Fig. 6) as well as the marked decrease of $\mathrm{A} / \mathrm{G}$ ratio in this series (Table 1). Considering the patterns of albumin and globulin, recalculation of kininogen

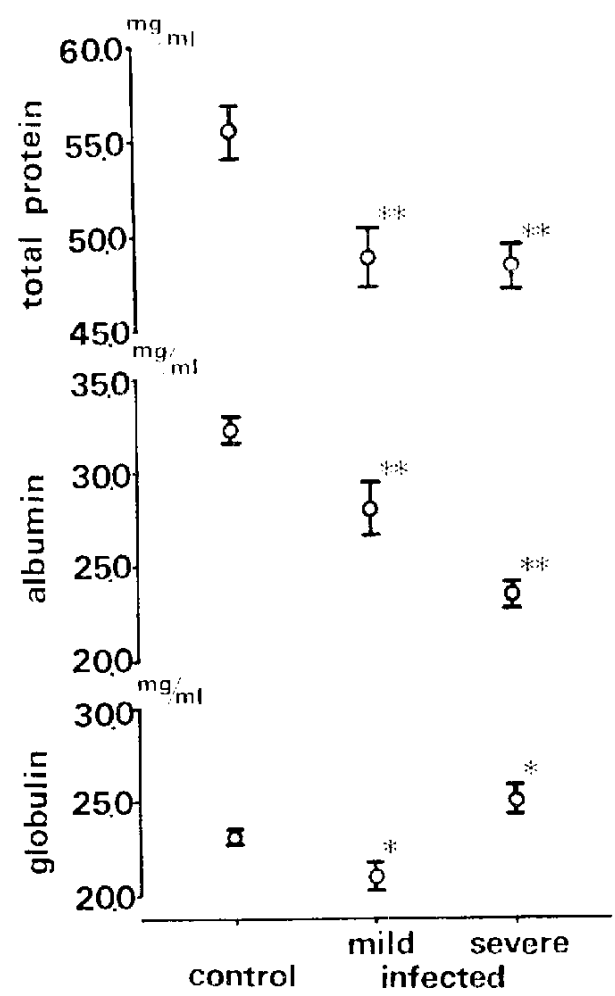

FIG. 6. Changes of total plasma protein, albumin and globulin in the control and the infected mice.

The values in both cases of the infected mice were compared with those in the control cases. The numbers of mice used in the control, mild and severe cases were $18,10,15$ respectively. Mean + standard crror. *p<0.05 **p<0.01.

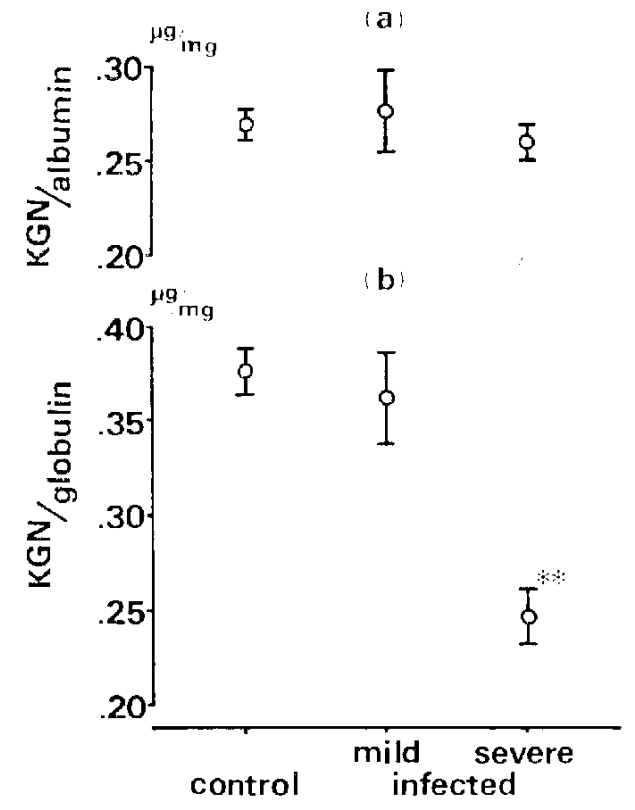

Fio. 7. Kininogen contents per $\mathrm{mg}$ albumin (a) and globulin (b) in the control and the infected mice.

The kininogen contents per $\mathrm{mg}$ albumin were not different among the threc groups. The kininogen content per mg globulin in the severe cases decreascd clearly (** $\mathrm{p}<0.01$ ), whereas that in the mild cases was not different from that in the control. The numbers of mice used are the same as in Fig. 6. Mean - standard error. $K G N$, kininogen. 
TABLF 2. Kininogen amounts in whole plasna and albumin and globulin fractions.

\begin{tabular}{|c|c|c|c|c|c|}
\hline & No. of expel & riments & I & II & III \\
\hline & Whole plasma & $(, \cdot \mathrm{g} / \mathrm{n} 1)$ & 5.20 & 5.60 & 5.60 \\
\hline & Albumin & (ng/ml) & 0.00 & 0.00 & 0.00 \\
\hline & Globulin & $($ (egml) & 3.79 & 4.00 & 4.24 \\
\hline & Recovery & $(\%)$ & 72.9 & 71.4 & 75.7 \\
\hline
\end{tabular}

The values for the whole plasma were obtained without running after application of 24,1 of plasma on the cellulose acetate membrane. Other $24 \mu 1$ of the same plasma was fracionated on the mombrane. Albumin and globulin were used for kininogen determinations. Recovery means the percentage of kininogen in globulin fraction against that of whole plasma.

contents per mg globulin might clarify whelher true consumption of kininogen occurred or not, since kininogen is present in globulin fraction and its amount per mg globulin must be reduced after consumption.

As shown in Fig. 7 (b), the kininogen content per mg globulin was reduced significantly in the severe group $(0.245 \pm 0.015 \mathrm{gg} / \mathrm{mg} ; \mathrm{p}<0.01)$, compared with that in the control group $(0.376+0.011 / \mathrm{g} / \mathrm{mg})$. Again that of the mild group was not reduced significantly $(0.362 \pm 0.025 \mathrm{gg} / \mathrm{mg} ; \mathrm{p}>0.25)$. Consequently, it could be concluded that the kininogen was not consumed in the mild group in any aspect. It is plausible that the kininogen contents per mg albumin in the mild and the severe groups were not significantly different from the kininogen of the control group, as shown in Fig. 7 (a).

In addition, kininogen was not detected from the albumin fraction after separation by electrophoresis on the cellulose acetate membrane, whereas kininogen was present in the globulin fraction, as shown in Table 2. The values of recovery were $72.9,71.4,75.7 \%$, when comparcd with the whole plasma which was applied on the membrane and was eluted by $0.01 \mathrm{~N} \mathrm{NaOH}$ without running on the membrane.

From the results of the kininogen experiments, the following can be concluded: a) In the severe cases, the kininogen was consumed even in consideration of protein or globulin concentrations in plasma. b) In the mild cases, in spite of the significant reduction of kininogen per $\mathrm{ml}$ plasma, the kininogen did not appear to be consumed, when expressed as $y=$ ing protein or globulin.

\section{Free kinin}

In order to know whether or not reduction of kininogen in plasma was really coupled with kinin release, free kinin in vcnous blood was studied.

Free kinin contents in plasma of infected and non-infected mice were plotted against the degrees of parasitaemia, as shown in Fig. 8 . In 6 non-infected mice, the amount of free kinin were so small that all values were less than $1 \mathrm{ng} / \mathrm{ml}$ of blood. In the mild group of the infected mice (4 cases), kinin was detected in the same amounts as the control group. This finding coincided well with the conclusion of the kininogen experiments, that kininogen was not consumed. On the contrary, the venous blood from mice of the severe gourp (18 cases) contained much larger amounts of kinin. The values were scattered from 1 to 
$98 \mathrm{ng} / \mathrm{ml}$ blood, but a definite relationship between the amounts and the degrees of parasilaenial did not seem to be present, in spite of the tendency for the kinin amounts to increase with the severity of parasitacmia. As the findings were in good agreement with the results of the kininogen experiments, the reduction of kininogen conlents in the severe group was concluded to be the real consumplion in coupling with kinin release.

Kininase aciivity

Kininase activity was determined with plasma of mice in the control $(9$ cases), mild (7 cases) and severe groups (14 cases), as shown in Table 3. When the activity of kininase in plasma was expressed as the half-life of bradykinin added to the incubation mixture, that of the eontrol mice ranged from 3.7 to $5.7 \mathrm{~min}$ and the mean value \pm S.E. was $4.7 \pm 0.2$ min. The acti-

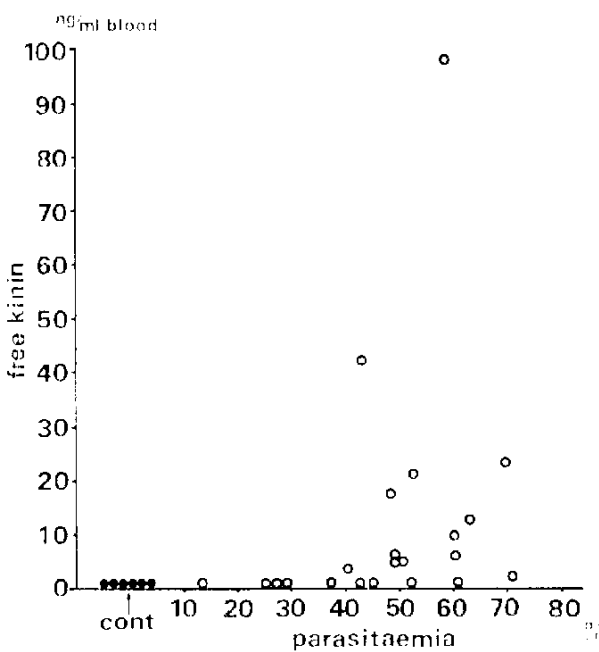

Fici. 8. Free kinin in venous blood of the control and the infected mice.

Ordinate, kinin extracted from the venous blood (ng/ml blood); abscissa, the degres of parasitaemia (\%). The amounts of kinin less than $1 \mathrm{ng} / \mathrm{nll}$ were plotted as $1 \mathrm{ng} / \mathrm{ml}$ of kinin. Clused circle, control (cont); open circle, infected.

vitics in mice of the mild and the severe infection were $2.0+0.6 \mathrm{~min}$ and $1.4+0.2 \mathrm{~min}$ respectively (mean \pm S.E.). Both activities were increased significantly $(p<0.01$ ), compared with the activity in the control mice. There was, however, no difference between the two groups of infected mice.

\section{Sisternic anterial pressure}

Since the involvement of the kinin system was proved in the severe cases of the malarial infection in the present paper, the pathophysiological significance of the system was studied.

Systemic arterial pressure of the infected and the non-infected mice was determined and the values obtained are plotted against the degrees of parasitaemia (Fig. 9). The arterial pressure in the control mice was $80.2 \mathrm{mmlg}$ as average, ranged from 60 to $94 \mathrm{~mm} \mathrm{Hg}$ with 13 mice, whereas the arterial pressure of the infected mice was scattered from 35 to 65

Table 3. Plasma kininase activity of the control and the infected mice.

\begin{tabular}{lccc} 
& & & Infected \\
& Control & Mild & Severe \\
Parasitaenia & & below $30 \%$ & above $30 \%$ \\
No. of animals & 9 & 7 & 14 \\
Half-life of bratykinin (min) & $4.7-0.2$ & $2.0 \quad 0.6^{* k *}$ & $1.4 \pm 0.2 *$ \\
\hline
\end{tabular}

Kininase activity was expressed as malf-life of bradykinin.

Mean : standard error. **: significanty higher activity than that in the control $(\mathrm{p} 00.01)$. 
$\mathrm{mmHg}$ with the mean value of $51.4 \mathrm{mmHg}$. Though the apparent relationship between the arterial pressure and the degrees of parasitaemia did not seem to be present, it could be said within the limits of this experiment that the infected mice showed hypotension. This finding might suggest that kinin extracted from the venous blood of the infected mice decreased the systemic arterial pressure. However, in order to explain the hypotension with cxtracted kinin, other proofs on the presence of the circulating kinin should be provided. In the present investigation, a preliminary experiment was done with bradykinin polentiator $\mathrm{C}$.

When the circulating kinin was present, further hypotension could be expected in the infected mice after intravenous injection of potentiator $C$. The slow and carcful injection of $0.3 / \mathrm{gg}$ or $3 \mathrm{rg} / 10 \mathrm{~g}$ body weight of potentiator $C$ through jugular vein of mice produced no hypotension not only in the control mice, but also in the infected mice with parasiaemia between 16.0 and $60.4 \%$. The amount of potentiator $\mathrm{C}$ was sufficient so that it potentiated the hypotensive responses to $0.1, \mathrm{~g} / 10 \mathrm{~g}$ of bradykinin by

TABLE 4. Systemic arterial pressure and hypotensive responses to bradykinin in the control and the infected mice.

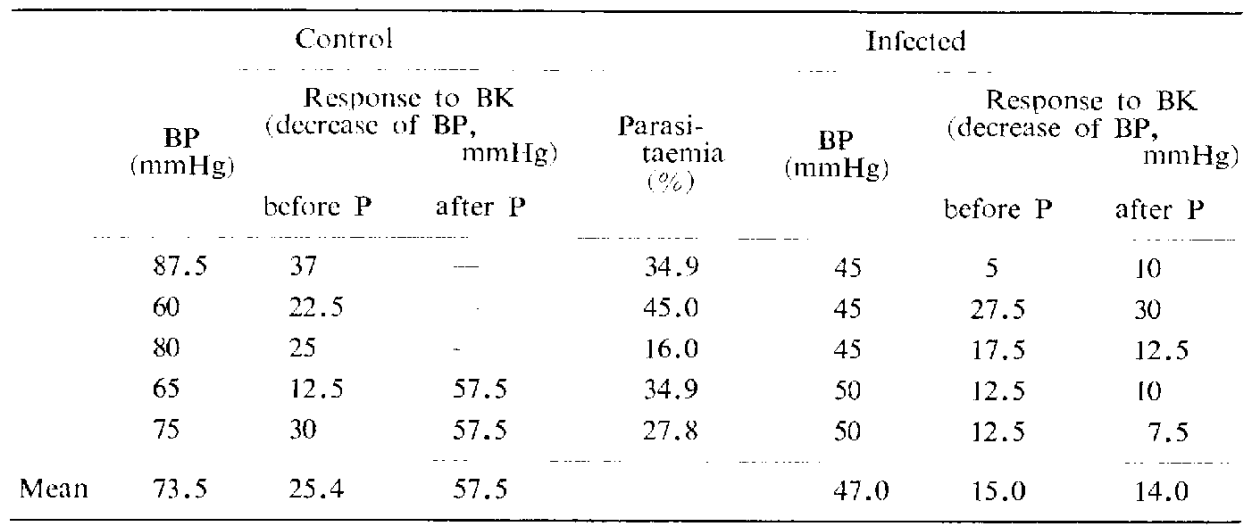

BP, systemic arterial pressure;

BK, bradykinn $(0.1 / 10 \mathrm{~g}$ i.v. $)$;

$\mathrm{P}$, bradykinin potentiator $\mathrm{C}(0.3, / \mathrm{g} / 10 \mathrm{~g} \mathrm{i}, \mathrm{v}$.

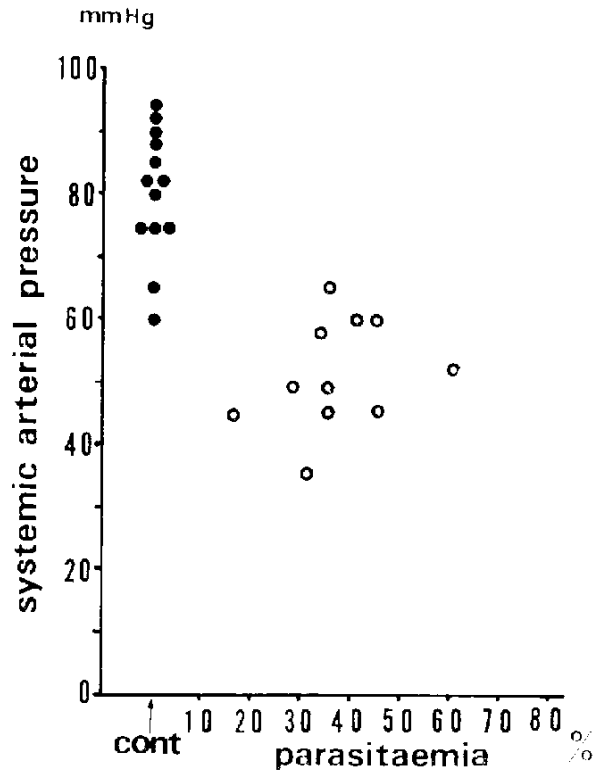

FiG. 9. Systemic arterial pressure under anesthesia in the control and the infected mice.

Ordinate, systemic arterial pressure $(\mathrm{mmHg})$; abscissa, the degrees of parasitaemia $(\%)$. The numbers of mice used were 13 for the control and 11 for the infected. Com, control. 
3 to 5 times in the control mice. It was found, however, that this method was not satisfactory, because bradykinin injected intravenously was not cnhanced after potentiator $\mathrm{C}$ in the cases of the infected mice. As shown in Table 4, the hypotensive responses to 0.1 ag/ $10 \mathrm{~g}$ of bradykinin were less in the infected mice than in the control and potentiator $C$ did not potentiate the responses.

\section{DISCUSSION}

According to the pilot experiments with three mice inoculated with approx. $10^{7}$ parasitized red cells, parasitacmia began to increase on day 3 after inoculation and the parasitaemia became suddenly severe between day 5 and 6 . The results are not in agreement with the report given by Tella and Maegraith (14), that parasitaemia of mice increased gradually from day 1 after infection with $2 \times 10^{7}$ parasites/g body weight. The difference may be due to the strain of mice and parasite as well as the amount of the parasite used. Results in this paper however coincided with those in the other report (15).

Although it is preferable to follow biochemical alterations in plasma with one animal in the lapse of time after infection, experiments with mice make the realization impossible. Therefore, on day 7 of the infection, blood was drawn from mice under pentobarbital sodium anesthesia. Parasitaemia, haematocrit, protein, kininogen and $\mathrm{A} / \mathrm{G}$ ratio were assessed with blood from one animal.

In these experimental conditions, the possibility of the involvement of the kinin system was studied. The best way to prove the involvement is to detect free kinin in the pathological states. Free kinin was definitely detectable in the severe cases of malaria, as shown in Fig. 8. For free kinin, venous blood was collected, as $78 \%$ of circulating bradykinin disappears in a single passage of the pulmonary circulation in cats (16). Failure to detect kinin in the malaria-infected monkeys may be partly due to the utilization of the arterial blood (1).

Since the extracted substance contracted the isolated rat uterus in the presence of an anti-serotonin agent (BOL), relaxed the isolated rat duodenum and caused hypotension in rats, the substance could be considered as kinin. Furthermore, according to Brocklehurst and Zeitlin (7), recovery of other smooth muscle stimulants extracted by this method were reported in mean \pm standard deviation as follows; histamine, $0.4 \pm 0.8 \%$; 5 -hydroxytryptamine, $3.2 \pm 0.9 \% ; \mathrm{K}^{+}, 6.2 \pm 2.1 \%$ The recovery of bradykinin was $81.5+8.0 \%$ in their experiments with human blood, whereas in our experiments with human blood $70.8 \%$ was the average. Even considering the values with human blood in the present experiment, $50-57 \%$ recovery with mouse blood was low. Although the higher kininase activity of mouse plasma may be a conceivable explanation, addition of o-phenanthroline or acidification of $80 \%$ ethanol at pH 5 did not improve the degree of recovery.

Under these experimental conditions, the extracted amount of free kinin from blood of the control, non-infected mice was less than $1 \mathrm{ng} / \mathrm{ml}$ blood. In mild cases with less then $30 \%$ parasitaemia, the amount did not exceed that in the control mice, and this result casts doubt on the possibility of the involvement of the kinin system in the mild 
cases of the malarial infection in mice. On the contrary, in severe cases the values of frec kinin extracted were scattered but definitely increased, though clear relationship between the kinin amounts and the degrees of parasitaemia did not seem to be present. Because of the total exanguination from the jugular vein, artificial formation of kinin during collection. may be suspected but the careful avoidance of contact with the negative surface and the detection of a minimal amoun of kinin in the control and mild groups dispels any suspicion.

The involvement of the kinin system only in the severe cases was ensured even more by the consumption of kininogen in plasma. The kininogen concentrations per ml plasma were reduced in conjunction with the increased degress of parasitacmia (Fig. 3), in such a way that the concentrations were significantly lower not only in the severe cases but also in the mild cases, as far as those were expressed as ag per ml plasma (Fig. 4). The reduction of the plasma protein contents deserves serious consideration, however, as pointed out by Urbanity. Sailer and Habermann $(4,5)$. In the present experiments, calculation of kininogen contents per mg protein in plasmal revealed a clear reduction of kininogen in the severe group, but crased the diflerence of the kininogen concentrations between the control and the mild groups.

On the latter finding, it may be claimed that the kininogen contents should be expressed on the basis of globulin contents, instead of the total protein contents, since reduction of the total plasma protein in infections may be due to the reduction of allbumin. To clucidate this, albumin-globulin ratio was studied by electrophoresis on the cellulose acelate membrane. The kininogen contents were divided by the amounts of albumin or globulin obtained from $\mathrm{A} / \mathrm{G}$ ratio and the total protein concentration in plasma. As it was expected, that kininogens per $\mathrm{mg}$ albumin were not significantly different among three groups, because albumin concentrations were reluced with the increased severity of the disease (Fig. 6). The kininogen per $\mathrm{mg}$ globulin in the mild cases. however, was also not clearly different from that in the control group. The finding, that the significant decrease of kininogen per ml plasma in the mild cases was a false reduction, coincided well with no detection of kinin. From these results, we may conclude that the kinin system was involved only in the severe group of mice. Reduced amounts of albumin were also reported in mice with the lapse of time after inoculation by Tella and Maegraith (6), although the total scrum protein did not decrease in their experiment. The latter finding can be explained by the simultaneous increase of globulin. In the present experiments, the globulin amounts increased only in the severe cases of the infection, whereas those in the mild cases (below $30 \%$ in parasitacmia) decreased significantly.

Concerning the deternination method of kininogen, which was reported by Diniz. and Carvalho (10) and was used in this experiments, recent papers reported the contamination of bradykinin potentiator(s) besides released bradykinin after incubation of acidified, denatured plasma with trypsin $(11,12)$. Since this was confirmed by us and the improvement of the method has not been established, attention was paid as described in the methods of the present paper. 
The consumption of kininogen in the severe state of malaria confirmed qualitatively the findings reported by Tella and Maegraith (1) and Onabanjo and Maegraith (2). Accordings to the authore in monkeys infected by Plasmodium knowlesi, kininogen per $\mathrm{ml}$ plasma fell to $8 \%$ of the preinfection level or was depleted at the final stage, whereas kininogen level of mice in the present experiments did not fall to less than $37 \%$ for the lowest value in the severe group. The quantitative difference may be accounted for the preparatory process of plasma as well as experimental conditions including the species difference. Dialysis of the precipitate after $50 \%$ saturation by ammonium sulphate, which was used by these rescarchers (1), may reduce the kininogen contents, because Jacobsen reported that pscudoglobulin contains no substrate I (high molecular weight kininogen) (17).

Onabanjo and Maegraith also presented the paper, showing the increased numbers of the fraction containing kallikrein in serun of the primates infected by malaria after fractionation of plasma (2). Various tests with these fractions such as the vascular permeability and diapedesis of leucocytes in the skin and the brain were also done (18-21). The increase or activation of kallikrcin in plasma may be conceivable, and may explain the consumption of kininogen in plasma, but the plasma edetate stable substrate which they used for the substrate of kallikrein may have contained the reduced amount of kininogen I (high molecular weight kininogen), because contact with silicate powder induces the activation of the glass-activated plasma kallikrein and consumes kininogen $\mathrm{I}$.

In the present experiments, the kininase activity in plasma increased markedly in the infected mice. Part of the increased activity may be due to microscopical haemolysis, caused by the malarial infection, as erythrocytes have strong kininase activily. The same observation was reported in the P. Knowlesi-infected primates (3).

In the infected mice. systemic arterial pressure was significantly lower than that in the control mice, as reported in monkeys $(22,23)$. The observation may well be a reflection of the pathophysiological role of kinin, which was obviously extracted from blood with consumption of its precursor in plasma. The authors, however, are of the opinion that more definite evidence on the presence of the circulating kinin is necessary for explanatio nof the hypotension by the extracted kinin.

Intravenous injection of peptide-7ike kinin potentiators may be a trial to detect the circulating kinin in the blood stream. Kato and Suzuki isolated five bradykinin potentiators from the venom of a snake (Aghistrodon halys blomhoffii) (24)(25) and determined the amino acid sequence of three potentiators B, C and E (26-28), which were synthetized by Sakakibara et al. (29). Bradykinin potentiator $C$ has the following amino acid sequence; Pyr-Gly-Leu-Pro-Pro-Gly-Pro-Pro-Isolc-Pro-Pro. The pharmacological activities of kinin potentiator $\mathrm{C}$ are reported as enhancement of the contraction of guinea-pig ileum and the blood pressure fall by bradykinin and the inhibition of kininase and angiotensin-I converting enzyme in the lung (29).

It was expected that on intravenous injection of potentiator $C$ into mice of the severe cases of the infection might produce further continuous hypotension, when kinin is circu- 
lating in the blood strean. The results proved contrary. Systemic arterial pressure in the infected mice did not change, as in the non-infected mice, after slow injection of the peptide. However, the interpretation of the result was not so simple, because the intravenous injection of protentiator $\mathrm{C}$ failed to potentiate the hypotensive response to bradykinin in the infected mice. The amounts of potentiator $C$ used were 0.3 or $3 / \mathrm{gg} / \mathrm{log}$ body weight and were sufficient to enhance the response to bradykinin 3 to 5 limes als large as that before potentiator $C$. Consequently, even if circulating kinin is present, the intavenous injection of potentiator $\mathrm{C}$ could not produce further hypotension in the infected mice. The reason that the response to bradykinin was not enhanced by potentiator $C$ was not clatified in this experiment. It might be speculated that kininase in the lung had already been inactivated, in combination to the low reactivity of the blood vessels to bradykinin in the infected mice, as shown in Table 4. In any case, this may be one of the pathological features of the malarial infection in mice.

The presence of the circulating kinin in blood stream was challenged by another preliminary experiment; the increased permeability of venules. However, intravenous injection of $5 \%$ pontamine sky blue or colloidal carbon to infected mice did not reveal any obvious increase of the vascular permeability. Further study is necessary.

The systemic arterial pressure was significantly lower in the infected mice and the hypotension may be partly accounted for kinin extracted. The results of the present investigations however and not prove the active role of the detected kinin on the hypotension in the infected animals.

The involvement of the kinin system was proved in the severe cases with parasitacmia above $30 \%$, only when examined on the day 7 of infection. The results from mice cxperiments do not indicate however whether the same is true with the lapse of time after infection. Nevertheless, we know that mice with low parasitacmia on day 7 after inoculation increase their own degree of parasitaemia gradually within a week to become fatal. Therefore, the present results could be cxtrapolated to the course of the infection after inoculation.

The present results did not provide any clue on the mechanism of activation of the kinin system in mouse nalaria, however, since globulin fraction did increase in the severe group in the present experiment, the kinin release might be related to antigen-antibody reaction. Further studies are necessary on this respect.

\section{SUMMARY}

1. Mice were infected in malaria with Plasmodium berghei (NK 65). The degrees of parasitaemia on day 7 after inoculation were distributed from 4 to $72 \%$, having a peak between 30 and $40 \%$.

2. Kininogen contents per $\mathrm{ml}$ plasma on day 7 of infection decreased in conjunction with the increased degrees of parasitaemia. The kininogen contents were significantly reduced in the mild cases (below $30 \%$ of parasitaemia) as well as in the severe cases (above $30 \%$ of parasitaemia).

3. The increase of the degrees of parasitaemia was accompanied with the reduction 
of haematocrit, body weight and plasma protein concentration. The kininogen per mg protein was significantly reduced in the severe cases, whereas no reduction was observed in the mild cases.

4. The reduction of kininogen contents per mg globulin was again not significant in the mild cases, in spite of the signiticant reduction in the severe cases. The kininogen contents per mg albumin were not significantly different among the control, mild and severe groups.

5. Free kinin in venous blood increased in the severe cases, although it did not inccrease in the mild cases. It can be concluded from these results that the kinin system was involved in the severe cases, whereas the involvement was not clearly proved in the mild cases.

6. Kininase activity increased significantly in the infected mice.

7. Systemic arterial pressure was obviously lower in the infected mice than in the control mice. This finding might suggest that kinin extracted from blood of the infected mice decreased the systemic arterial pressure.

8. Bradykinin potentiator $\mathrm{C}$ from a snake venom was used to prove the circulating kinin in the role on blood stream, in connection with the role on low blood pressure of the infected mice. However, the trial was not successful, because, in the infected mice, dotentiator $\mathrm{C}$ did not potentiate the hypotensive responses to bradykinin.

Acknowledgements: We are grateful to Prof. R. Kano and his colleagues, Department of Medical Zoology, Faculty of Medicine, Tokyo Medical and Dental University, for the opportunity of exploring this field of study and also for helplul advice. Thanks are also due to Prof. T. Shigei, Nagoya University, to Prof. H. Maeda, Tokyo Medical and Dental University, to Associate Prof. M. Kobayashi, Gifu University, to Dr. M. Suzuki, The Institute of Medical Science, University of Tokyo, for encouragement and helpful discussions, and to Mr. M. Sekiguchi and Miss K. Abe for skillful technical assistance.

\section{REFERENCLS}

1) Tella, A. and Maegikniri, B.G.: Am. trop. Med. Parasit. 60, 304 (1966)

2) Onabanjo, A.O. and Makgral[i, B.G.: Br. J. exp. Path. 51, 523 (1970)

3) OnABanio, A.O., Bhabani, A.R. nмD Mafgratth, B.G.: Br. J. exp. Paht. 51, 534 (1970)

4) Urbanitz, D., Sailer, F. and Habermann, E.: Adv. exp. Mel. Biof. 8,343 (1970)

5) Ilabekmani, E.: Handb. c.xp. Pharmak. 25, 250 (1970)

6) Tild A, A. And Maigraith, B.G.: Amn. trop. Med. Parasit. 59, 153 (1965)

7) Yoel, M.: Trans. R. Soc. trop. Med. Hyg. 59, 255 (1965)

8) Munsick, R.A.: Findocrinolugy 66, 451 (1960)

9) Brocklehurst, W.E. And Zeiniln, I.J.: J. Physiol. 191, 417 (1967)

10) Diniz, C.R. and Carval.ho, I.F.: Anh. N.Y. Acud. Sci. 104, 77 (1963)

11) Aarsen, P.N.: Br. J. Pharmac. Chemother. 32, 453 (1968)

12) Hamberg, U., Ei.g, P. and Stelivagex, P.: Seand. J. cilin. Lab. Invest. 24, Suppl. 107, 21 (1969)

13) Lowry, O.H., Rosexbrough, N.J., Farr, A.L. ANI Randall, R.J.: J. biol. Chem. 193, 263 (1951)

14) Tella, A. and Maegraith, B.G.: Ant. trop. Mcd. Parasit. 59, 135 (1965) 
15) Welldi, B.T., Briggs N.T. and Sadun, E.H.: Military Medicine 131, Suppl. 859 (1966)

16) Ferreitra, S.11. And Vane, R.H.: Br. J. Pharmac. Chemother. 30, 417 (1967)

17) JACOBSEN, S.: Br. J. Pharmac. Chemother. 26, 403 (1966)

18) Onabanjo, A.O. and Malgraith, B.G.: Trans. R. Soc. trop. Med. Hyg. 63, 2 (1969)

19) Ovabanjo. A,O. and Matciratth, B.G.: Adl. exp. Med. Biol. 8, 411 (1970)

20) Onabanjo, A.O. ANd Mafiraith, B.G.: Ann. trop. Med. Parasit. 64, 227 (1970)

21) Onabanjo, A.O. mid Malgraitu, B.G.: Amir. trop. Med. Parasit, 64, 237 (1970)

22) Maegraith, B.G., Devakul, K. A^d Llithead, C.S.: Am. trop. Met. Parcisit. 53, 358 (1959)

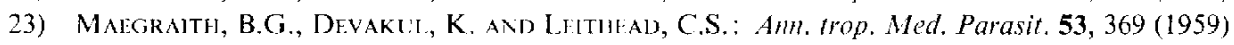

24) Kato, H. AхD SLzuki, T.: Experichia 25, 694 (1969)

25) Kato, H. ANd Suzcki, T.: Adv. exp. Med. Biol. 8, 101 (1970)

26) Kato, H. and Suzuki, T.: Proc. Japan Acad. 46, 176 (1970)

27) Kato, H. ANd Suzuki, T.: Experiemia 26, 1205 (1970)

28) Kato, H. A.ND SUzUKI, T.: Biochemistry 10, 972 (1971)

29) Kimura, T., Kato, H., Sakakibaka, S. and Suzuki, T.: The $2 m$ am. Peptide Symp. (1970) 